\title{
Single Calcium Channel Activity in Mouse Pancreatic $\beta$-Cells
}

\author{
F. M. ASHCROFT, ${ }^{a}$ P. RORSMAN, ${ }^{b}$ AND G. TRUBE $^{c}$ \\ ${ }^{a}$ University Laboratory of Physiology \\ Oxford University \\ Oxford, United Kingdom \\ ${ }^{b}$ Department of Medical Physics \\ Göteborg University \\ Göteborg, Sweden \\ ${ }^{c}$ Max Planck Institute für Biophysikalische Chemie \\ Göttingen, Federal Republic of Germany
}

Glucose-induced insulin secretion from pancreatic $\beta$-cells is known to involve an influx of calcium through voltage-dependent $\mathrm{Ca}$ channels. Recently we have recorded singlechannel currents flowing through $\beta$-cell $\mathrm{Ca}$ channels using the outside-out configuration of the patch-clamp technique and $\mathrm{Ba}^{2+}$ as the charge carrier. ${ }^{1}$ Only one type of $\mathrm{Ca}$ channel was observed. This had a single-channel slope conductance of $24 \mathrm{pS}$ in $110 \mathrm{mM} \mathrm{Ba}{ }^{2+}$, was sensitive to dihydropyridines, and was blocked by micromolar concentrations of $\mathrm{Cd}^{2+}$. These properties are consistent with the view that this $\mathrm{Ca}$ channel is of the L-type (for terminology see Nowycky et al. ${ }^{2}$ ). The outside-out patch configuration involves the replacement of the cytosol with an artificial solution and is therefore unsuitable for investigations of the metabolic regulation of the $\mathrm{Ca}$ channel. For these studies we have used cell-attached patches, because $\mathrm{Ca}$ channels are then exposed to their normal internal environment. We present here preliminary cellattached recordings of single Ca channels in mouse pancreatic $\beta$-cells, using previously published methods. ${ }^{1}$

FIGURE 1 shows single-channel currents recorded from a cell-attached patch on a $\beta$-cell immersed in normal external solution containing (in $\mathrm{mM}$ ): $138 \mathrm{NaCl}, 5.6$ $\mathrm{KCl}, 1.2 \mathrm{MgCl}_{2}, 2.6 \mathrm{CaCl}_{2}$, and $10 \mathrm{HEPES}-\mathrm{NaOH}$ (pH 7.4). The pipette was filled with (in $\mathrm{mM}$ ) $100 \mathrm{BaCl}_{2}, 10 \mathrm{TEACl}, 10 \mathrm{HEPES}-\mathrm{Ba}(\mathrm{OH})_{2}(\mathrm{pH} \mathrm{7.4)}$. In the absence of glucose, most channel openings were of brief duration and long openings were observed only rarely. One minute after the addition of $20 \mathrm{mM}$ glucose to the bath solution, channel activity was greatly increased and long openings predominated. The associated mean current is consequently considerably larger in the presence than in the absence of glucose. The channel openings have the same amplitude in the presence and absence of the sugar, excluding the possibility that the effect is due to $\beta$-cell depolarization. In fact, the single-channel current (I)-voltage (V) relations recorded under both conditions superimpose. After three minutes in high glucose, the $\beta$-cell fired action potentials, which frequently elicited Ca-channel openings. These preliminary findings suggest that glucose might modulate Ca-channel activity in the $\beta$-cell. A related phenomenon has been described in an insulin-secreting cell line. ${ }^{3}$

The single-channel slope conductance was $20 \pm 2 \mathrm{pS}(n=6)$ when measured in 
A.

Control

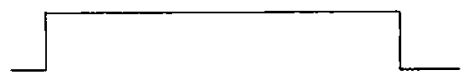

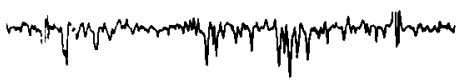

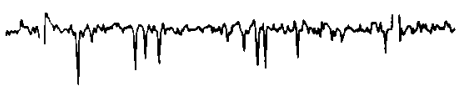

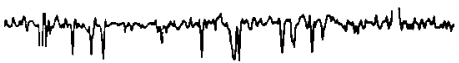

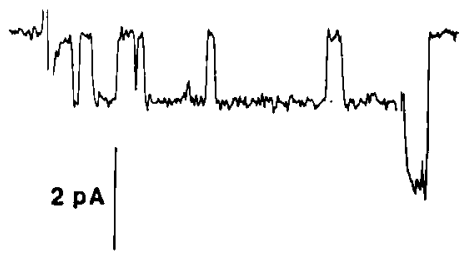

C.

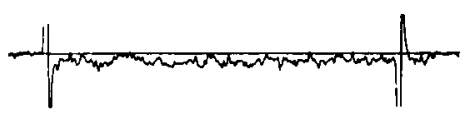

$0.5 \mathrm{pA} \mid \overline{25 \mathrm{~ms}}$
B.
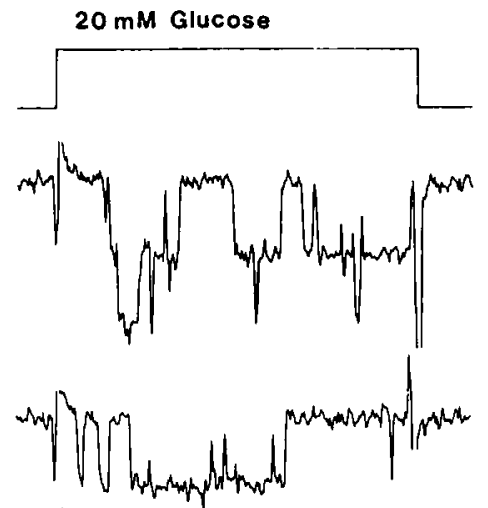

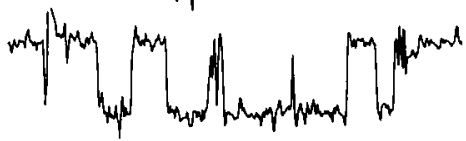

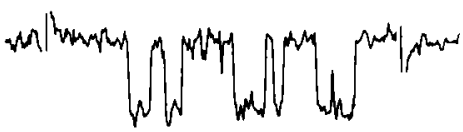

D.

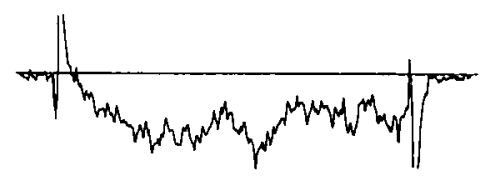

FIGURE 1. Single Ca-channel currents recorded from a cell-attached patch on a mouse $\beta$-cell immersed in normal external solution. Pulses were applied from a pipette holding potential of $0 \mathrm{mV}$ to a pipette potential of $-70 \mathrm{mV}$ (assuming a $\beta$-cell resting potential of $-70 \mathrm{mV}$, this corresponds to a membrane potential of $0 \mathrm{mV}$ ) at a frequency of $0.5 \mathrm{~Hz}$. Records were filtered at $0.5 \mathrm{~Hz}$. (A) Ba currents recorded in the absence of glucose. (B) Ba currents recorded one minute after increasing the bath glucose concentration to $20 \mathrm{mM}$. (C,D) Associated mean currents for the data in A,B obtained by averaging approximately 50 individual sweeps. 
normal extracellular solution. I-V relations were also recorded in a depolarizing, high $\mathrm{K}^{+}$solution, which allows better control of membrane potential (in $\mathrm{mM}: 125 \mathrm{KCl}$, $30 \mathrm{KOH}, 1 \mathrm{MgCl}_{2}, 2 \mathrm{CaCl}_{2}, 10 \mathrm{EGTA}$ and $\left.5 \mathrm{HEPES}-\mathrm{KOH}, \mathrm{pH} 7.15\right)$. In this solution, the single-channel conductance was $25 \pm 2 \mathrm{pS}(n=4)$ and the I-V relation was shifted by $70 \mathrm{mV}$ with respect to that recorded in normal external solution, consistent with the usual $\beta$-cell membrane potential of around $-70 \mathrm{mV}$. Ca-channel activity was markedly increased by $5 \mu M$ BAY K 8644 and inhibited by $25 \mu M$ D 600 .

Our preliminary studies suggest that the use of cell-attached patches will be valuable in future studies concerning the regulation of $\mathrm{Ca}$-channels in $\beta$-cells, and corroborate the view that, at least in mouse $\beta$-cells, L-type Ca channels contribute to most of the Ca current involved in the process of insulin release.

\section{REFERENCES}

1. Rorsman, P., F. M. Ashcroft \& G. Trube. 1988. Pflugers Arch. 412: 597.

2. NowYCKY, M. C., A. P. FoX \& R. W. TsIEN. 1985. Nature 316: 400.

3. Velasco, J. M., J. U. H. Petersen \& O. H. P. Petersen. 1988. FebS Lett. 231: 366. 